\section{Middelaldermusik i Danmark}

Af professor, dr.phil. John Bergsagel

$\mathrm{I}$ et fransk håndskrift fra 800-tallets anden halvdel er der på en ledig plads indføjet en indtrængende bøn om beskyttelse imod de vilde vikinger, der i de år hærgede det nordvestlige Frankrig: De gente fera Normannica nos libera, quae nostra vastat Deus regna senum jugulat et juvenum ac virginum puerorum quoque catervam. ${ }^{1}$ Teksten ledsages af musik, $\mathrm{i}$ form af noder skrevet in campo aperto (dvs. uden et liniesystems angivelse af tonehøjde), som derfor ikke tillader, at melodien kan genskabes med sikkerhed. Men konkordanser viser, at bønnen er en del af en sekvens, Gaude eia unica, som tilhører en gruppe af beslægtede sekvenser, hvis melodi kan gengives fra senere forekomster skrevet på linier og som går under navnet Concordia. ${ }^{2}$ Denne er sandsynligvis den første - lidet smigrende - omtale af vikingerne (herunder danskerne) i musik, men af vikingernes egen musik er intet overleveret.

$\mathrm{F}$ or at finde frem til de sparsomme oplysninger, der findes om musiklivet i Danmark i perioden op til og omkring kristendommens indførelse (800-1100-tallet) må man opsøge de litterære kilder, Eddaerne, sagaerne og krønikerne, som også Saxo Grammaticus gjorde i sin historie om det danske folk, Gesta Danorum (ca. 1200). Her kan man læse om musikkens magt, f.eks. over Kong Erik Ejegod (12. bog), som dræbte fire mænd under påvirkning af en omrejsende musikers harpespil. Arild Huitfelds genfortælling af denne historie i Danmarckis Rigis Kronike IV (1603), er i margenen ledsaget af navnet "Rammaslag", som også er navnet på en af melodierne spillet med magisk virkning af eventyreren Bósi ved en bryllupsfest på Kong Godmundrs hof i Bósa saga. Omrejsende spillemænd og gøglere (leikarar) er ofte omtalt med foragt (f.eks. Saxo, 1. bog), medens sangere og digtere nyder en højere anseelse. I 1200- og 1300tallet opsøgte berømte tyske Minnesangere, såsom Reinmar von Zweter, Tannhäuser, Rumelant og Frauenlob, de danske hoffer og fejrede danske konger og begivenheder. Den tidligste verdslige sang på dansk, som er skriftligt overleveret med sin melodi, er et ballade-

fragment, "Drømdæ mik en drøm inat", skrevet i runer, med musikken i en urytmiseret notation på et fire-liniet system, $i$ begyndelsen af 1300-tallet på en ledig plads i en afskrift af Skånske Lov (Codex runicus). ${ }^{3}$

$\mathrm{M}$ ed kristendommens indførelse arvede Danmar en højtudviklet international musikkultur, men desværre også på dette område er der kun overleveret få vidnesbyrd om danske bidrag til musikdyrkelse. De første missionærer, af hvem Skt. Ansgar (ca. 825) nok har været den mest betydningsfulde, kom fra Tyskland, men større indflydelse havde engelske missionærer i 1000-tallet. Engelske helgener som Oswald og Alban blev for eksempel 
dyrket i Odense (hvor der var relikvier), og da Kong Knud den Hellige blev dræbt foran alteret i Skt. Albans kirke i Odense i 1086, blev engelske munke hentet dertil af hans bror, Kong Erik Ejegod, for at dyrke hans minde. Da Knud som den første danske kristne martyr (protomartyr danorum) blev helgenkåret i 1100 eller 1101, blev der naturligvis komponeret nye tilføjelser til kirkens liturgiske repertoire (almindeligvis kaldede hystoria, fordi de fortæller historien om helgenens liv, død og undergerninger), som disse begivenheder lagde op til. De udgør et Officium, en cyklus af liturgiske handlinger, som munkene på et kloster påtog sig at udføre døgnet igennem på helgenens festdag eller dage - i Skt. Knuds tilfælde den 10. juli (den dag han led martyrdøden) og 19. april (den dag, han blev translateret i forbindelse med helgenkåringen). Musikken til disse gudstjenester er den første vi kan være sikre på nødvendigvis må være blevet til på dansk jord, men den er desværre forlængst gået tabt. Kong Knuds Officium er idag stort set kun kendt fra de liturgiske bøger, der blev trykt for de danske stifter ved middelalderens udgang, for kort efter at blive afskaffet af reformationen. Her er dets oprindelige udformning til monastisk brug blevet revideret til en "sekulariseret" (dvs. ikke-monastisk) version, og naturligvis kunne musikken ikke trykkes. Indtil videre er vort kendskab til musik for Skt. Knud rex begrænset til nogle hymner og sekvenser, hvis melodier kan identificeres andetstedsfra. ${ }^{4}$ Men til alt held er Officiet som blev komponeret til hans nevø, Knud $d u x$
(Knud Lavard), som blev dræbt ved et snigmord i Haraldsted Skov nær Ringsted den 7. januar 1131 og helgenkåret som Danmarks anden helgen den 25. juni 1170 , bevaret i sin helhed i en afskrift fra 1200-tallet nu i Kiels Universitetsbibliotek. ${ }^{5}$ Håndskriftet indholder et omfattende materiale: hele det liturgiske forløb for Skt. Knud Lavards to festdage, komplet med musik, samt en afskrift af Roskildekroniken. Den liturgiske del er sandsynligvis det Officium, der blev forberedt for helgenkåringsfestligheden $\mathrm{i}$ den nuværende Skt. Bendts kirke i Ringsted den 25. juni 1170, og er således den tidligste overlevede musik komponeret i Danmark og som sådan et uvurderlig klenodie. Ligesom Skt. Knud kongens Officium, udviser dette spor af en-gelsk indflydelse, for eksempel i den særprægede hymne Gaudet mater ecclesia, som synges ved 1 . Vespers (og andre steder) i Knud Lavards Officium. Spørgsmålet er, om den egentlig er tostemmig, på trods af at den er skrevet enstemmigt $\mathrm{i}$ håndskriftet. Melodien består af to dele, en opadgående og en nedadgående, og hvis halvdelen af koret begynder melodien i midten, samtidig med at den anden halvdel begynder ved begyndelsen, udgør de to dele tilsammen et velklingende og for sin tid korrekt, kontrapunkt. Syngemåden kaldes rondellus, og grunden til, at der er en reel mulighed for, at hymnen blev sunget på den måde er, at den findes nedskrevet sådan, tostemmigt (dog med en anden tekst), i to engelske håndskrifter. ${ }^{6}$ Gaudet mater ecclesia er alligevel anderledes end de engelsk hymner, for så vidt som hymnens anden strofe ledsages af en anden 


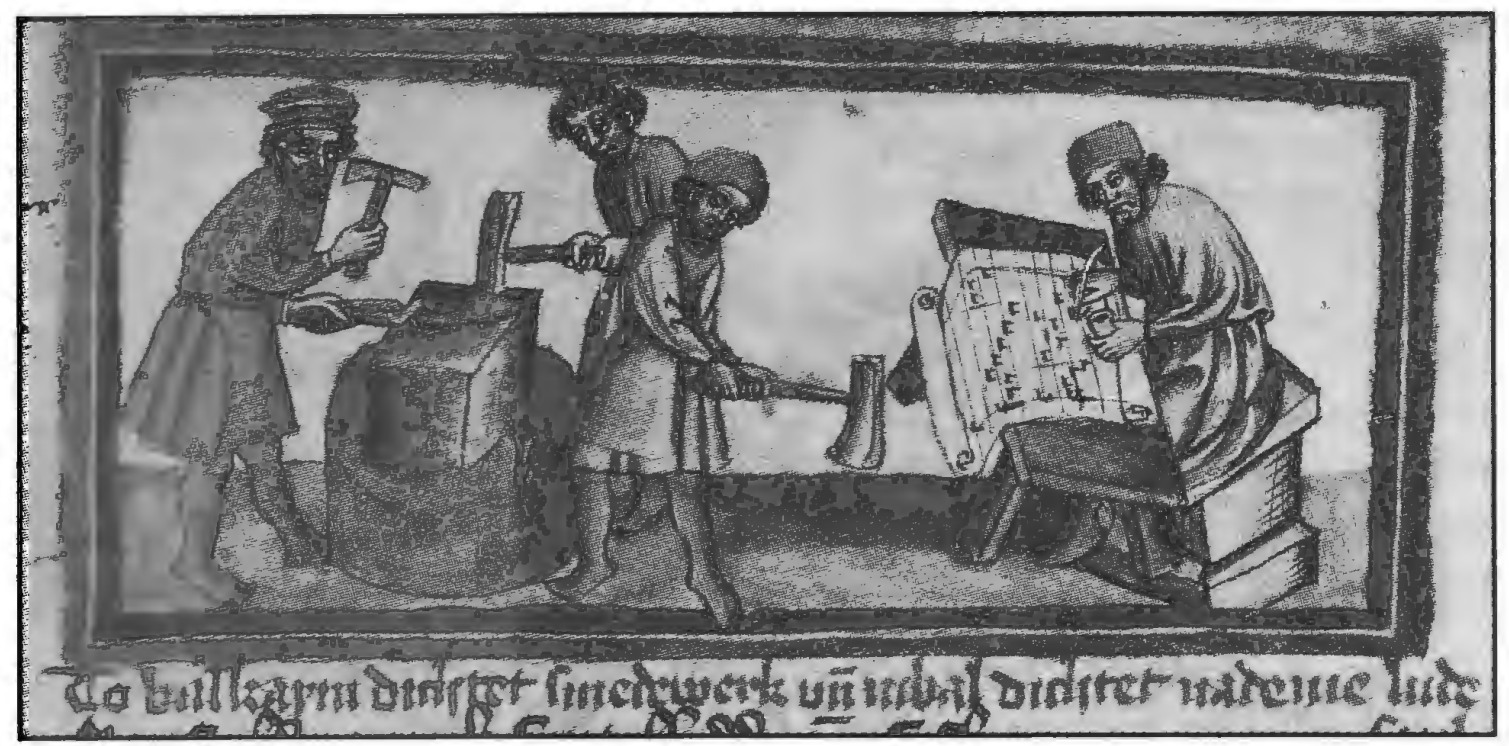

Tuba-Kain, smedenes stamfader og Jubal, "stamfader til alle dem, der spiller på citer og fløjte" (1. Mosebog, kap. 4), her fremstillet som nodeskriver. Fra Den menneskelige frelses spejh Tyskland, første halvdel af 1400-tallet.

melodi. Denne melodi (også kendt i engelske kilder) er dobbelt så lang som den første, men også den kan opføres som rondellus. ${ }^{7} \mathrm{Om}$ meningen har været, at hymnen skal synges ved at skifte melodi strofe for strofe, eller om de to er alternative melodier, er ikke klart.

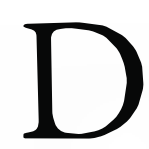

a Skt. Laurens kirke i Lund blev ophøjet til ærkebispesæde i 1103, fik den nye domkirke Nordens første spæde korstatutter. Nogle sekvenser skrevet i Lunds "gavebog" (Liber daticus Lundensis, ca.1170) ${ }^{8}$ vidner måske om forbindelser til Frankrig og det nye universitet i Paris, men meget lidt kendes til musikken i de danske kirker fra denne tid. I tusindvis af liturgiske musikhåndskriftfragmenter findes opbevaret på danske biblioteker og arkiver men er endnu ikke blevet registreret, og om nogle er af dansk oprindelse, er ikke blevet påvist. Udover den traditionelle enstemmige liturgiske sang dannede den middelalderlige kirke rammen om nogle musikalske udviklinger, som har været af den største betydning for den vestlige kultur, også udenfor kirken. I 800-tallet møder man rundt om i Europa et ønske om at visualisere eller dramatisere, om man vil, vigtige bibelske historier (f.eks. Christi fødsel, opstandelse eller himmelfart, Mariae bebudelse eller historien om Daniel) eller moralske fortællinger. De, der var bibelske, blev så vidt muligt opført i tilknytning til en gudstjeneste og har fået betegnelsen liturgisk drama, hvorimod de, der ikke hørte hjemme indenfor kirken, kunne opføres udenfor kirkedøren og ofte omtales som mysteriespil. Disse mere eller mindre iscenesatte og rollebesatte "skuespil" har făet en vigtig plads $\mathrm{i}$ teaterhistorien, og for så vidt som de også blev sunget, vil nogle $\mathrm{i}$ dem finde kernen til den meget senere opståede operagenre. Et enkelt blad af 
det velkendte liturgiske spil Visitatio Sepulchri på Rigsarkivet sandsynliggør, at denne kunstneriske udvidelse af den kirkemusikalske praksis har fundet sted også i Danmark. ${ }^{9}$ Endvidere er orgler omtalt i danske domkirker fra 1200 tallet (Ribe 1290, Lund ca.1330), og et stort intrumentarium er skildret på kalkmalerier i danske kirker, men ingen instrumentalmusik har tilsyneladende overlevet.

S elv de vanskelige forhold vedrørende musikalsk kildemateriale fra middelalderen taget $i$ betragtning er det bemærkelsesværdigt og skuffende (for ikke at sige foruroligende), hvor få vidnesbyrd der er blevet os forundt om flerstemmig sang i Norden. Om den sofistikerede tostemmige flerstemmighed, som Kong Knud den Store må have hørt i sin engelske hovedstad Winchester i det tidlige 1000-tal, er der intet tegn, heller ikke af den højtudviklede flerstemmige musik, som nordiske studerende i Paris i 1100- og 1200-tallet, heriblandt de senere ærkebiskopper $\varnothing$ ystein i Nidaros, Anders Sunesøn i Lund og Nils Allesson in Uppsala, må have erfaret og blevet begejstrede af. Alligevel kan man formode, at sådan musik - eller i hvert fald flerstemmig musik af en vis fordringsfuldhed - er blevet praktiseret nogle steder hos os, eftersom Nils Allessons korstatutter for Uppsala domkirke i 1298 specificerer, at de sangere, som udfører noget, der hedder organum, skal have ekstrabetaling. Hvis henvisningen gælder den flerstemmige musik, som først og fremmest er forbundet med Notre Dame domkirken i Paris i 1200- tallet (og det må man formode er tilfældet, udfra den opfattelse at det er særlige musikalske færdigheder, der skal belønnes) ${ }^{10}$, er intet af denne musik desværre blevet overleveret $i$ en nordisk kilde. Dog må det være tilladt i denne forbindelse at nævne en kilde, som, selv om den formodentlig er fransk, i mere end 600 år har været i dansk eje og nu er opbevaret på Det Kongelige Bibliotek. Kilden består af nogle musikfragmenter brugt som forsatssider ved indbindingen af en bog, ${ }^{11}$ som har tilhørt en dansk studerende, Peter Ingvarsen fra Ros-kilde (frater Petrus Inguari studens Roskildensis), der formodentlig har studeret ved universitetet i Paris i 1300-tallet. Senere kom bogen i Frederik I's livlæges besiddelse, hvorefter den blev indlemmet $\mathrm{i}$ den gottorpske hertugs bibliotek på Gottorp Slot for senere at blive overført til København. Forsatssiderne er blevet skåret fra en afskrift, der i sidste fjerdededel (?) af 1200-tallet blev lavet af en berømt samling kirkemusik, komponeret af magister Leoninus (ca.1180?) og omtalt af samtiden som Magnus liber organi ("den store organumbog"). Ingen af stykkerne er fuldstændige på disse fragmenter, men mere eller mindre betragtelige dele af ikke færre end syv organa er overleveret på disse sider. Håndskriftet, hvorfra de er blevet skåret for at skaffe pergament til indbindingsmateriale, har åbenbart været den seneste af de kendte afskrifter af Magnus liber organi og videregiver værdifulde oplysninger om denne musik, som vi ellers ikke har kendskab til. For eksempel har påskeantifonen Christus resurgens hidtil kun været kendt $\mathrm{i}$ en enstemmig version; den 


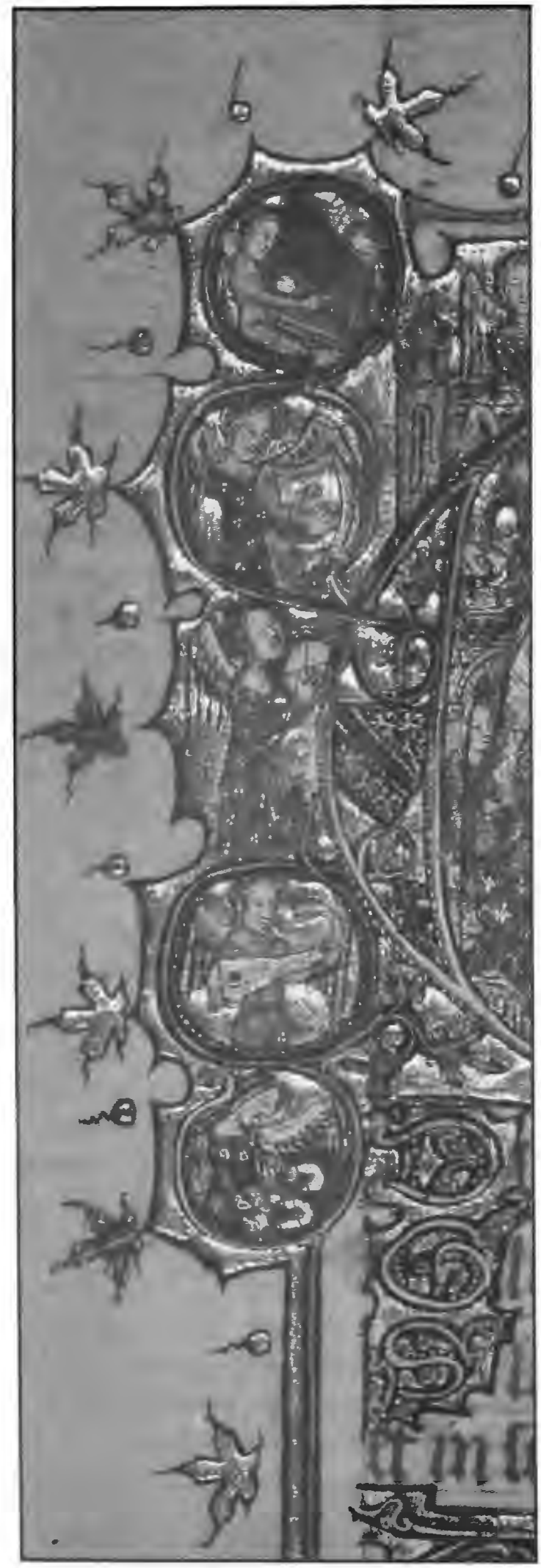

to-stemmige version i København er således et unikum. Derudover udviser notationen på disse fragmenter tegn på en mere fremskreden udvikling, som gør nedskrivningen af rytmiske værdier noget mere præcis, end tilfældet er i de andre håndskrifter. ${ }^{12}$

$1 \begin{aligned} & \text { t finde en måde at nedskrive } \\ & \text { noget så abstrakt som musik på, } \\ & \text { er selvsagt en vanskelig opgave, }\end{aligned}$ hvis to fundamentale krav må være at kunne angive både tonehøjde og rytme. Inden for det system, der over flere århundreder blev udviklet således at europæisk musik kunne overleveres, blev disse to problemer løst på forskellige tidspunkter: det at skrive præcise tonehøjder i begyndelsen af 1000-tallet ved at anbringe nodetegnene på et liniesystem, og det at få nodetegnene selv til at angive en tones præcise varighed $\mathrm{i}$ begyndelsen af 1300-tallet.

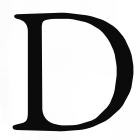
er er ingen tvivl om, at i hvert fald nogle dele af Leoninus' organa blev opført rytmiceret, men de samtidige teoretiske instrukser for, hvordan musikkens rytme blev realiseret i praksis, er langt fra utvetydige. Ideen var, at nogle (i alt seks) aftalte grupperinger af nodetegn hver skulle signalere et mere eller mindre regelmæssigt metrisk mønster (modus). Selv om dette unægtelig er et fremskridt, er

Initial med Marias himmelkroning og musicerende engle. Fra bonnebog lavet $i$ England ca. 1370. 
det ikke nok til at forhindre at forskellige forskere stadig i mange henseender kan fortolke denne vigtige musik, som er produktet $\mathrm{i}$ en skelsættende dynamisk periode i musikkens historie, på forskellig vis. Derfor er "Københavnerfragmenterne" på Det Kongelige Bibliotek særlig interessante, da de, indenfor rammerne af den gamle stils (ars antiqua) "modale" system, peger i retning af den præcisering af de enkelte noders rytmiske værdier, som karaktiserer den nye stil (ars nova) i det 14. årh. og danner grundlaget for vor moderne praksis. Her og der i den afskrift af Magnus liber organi, der blev ødelagt for at indbinde Peter Ingvarsens bog til hans studier ved Paris' universitet, har nodeskriveren med en vis konsekvens brugt nogle nye nodetegn, som gør det klart hvilke noder, der skal holdes længere end en normal lang node (longa), og især hvilke der skal opføres kortere end en normal kort node (brevis). Selv om der kun er tale om nogle fă af Leoninus' organa på disse fragmenter, føjer de oplysninger af stor værdi til den viden, vi har fra andre kilder, ikke mindst med hensyn til musikkens rytme i den sidste vanskelige fase, inden der blev udviklet en mere dækkende musikalsk notation. ${ }^{13}$

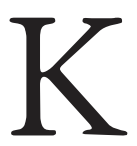

unsten at synge flerstemmigt var rimeligvis en del af musikundervisningen i katedralskolerne. I

1107 hentede biskop Jon af Holar en fransk clericus ved navn Rikinni til Island for at undervise i kirkemusik i den af ham nylig oprettede skole, men hvad undervisningen omfattede, făr vi ingen oplysning om. I en veletableret latin- skole var der undervisning i musik som en af de syv artes liberales, efter al sandsynlighed en undervisning hovedsageligt baseret på Boethius' overlevering af græsk musikteori på latin fra omk. år 500. Men eftersom det normalt var forventet at drengene assisterede ved gudstjenester i dom- og købstadskirkerne, var der nødvendigvis også en praktisk undervisning i kirkens liturgiske sang. En bog indeholdende to- og trestemmige satser (continentem discantus et tripleta), der blev testamenteret til Lunds katedralskole i 1358, er desværre gået tabt, men nogle brudstykker af elementær koralteori i en bog, med en samling af for-skelligartet materiale, som næppe kan forstås på anden vis, end at den har tjent som en lærers håndbog, er måske et sjældent vidnesbyrd om musikundervisning i skolen i middelalderen. Bogen, et dansk håndskrift fra ca. $1450,{ }^{14}$ omfatter bl.a. også en lille samling af seks tostemmige sange, den tidligste flerstemmige musik fundet $i$ en dansk kilde, som sandsynligvis har været sunget af skoledrengene også uden for deres kirketjeneste. For eksempel kunne Nicholai solempnia, synges i stedet for Benedicamus Domino ved messens slutning, men den har sikkert også været sunget som en kærlig hilsen til skoledrengenes skytshelgen, Skt. Nikolai (festdag 6. dec.), i dagene op til juleferien. Denne sang har forbindelser til Schlesien og understreger igen den internationale karakter, som musikken har haft i middelalderen, også i Norden. ${ }^{15}$ Af de seks kompositioner er kun Nicolai solempnia og nadverhymnen Jhesus Christus nostra salus, som tidligere har været tilskrevet den bøh- 
miske martyr Jan Hus, kendt fra andre (udenlandske) kilder. Dette tillader os ikke at konkludere, at de resterende stykker er af dansk oprindelse, men det er måske forsvarligt at formode (indtil videre), at den tiltalende dansk-sprogede $O$ rosa in iherico er en dansk komposition. Hvis opfattelsen, at bogen blev brugt i skoleundervisning, er korrekt, er der ikke noget at sige til, at de tostemmige kompositioner, der findes afskrevet heri, er enkle, ukunstlede stykker, som ikke giver grundlag for sammenligning i forhold til det høje niveau, som flerstemmig musik havde opnået på det tidspunkt andre steder i Europa med komponister som Dunstable, Dufay og Ockeghem.

Noter

1 Paris, Bibl. nat. lat. 17436, den såkaldte "Antiphonar af Karl den Skaldede" fra Abbaye de St. Corneille i Compiègne, f.24. Faksimile i Den 22. Europarådsudstillingskatalog, Viking og Hvidekrist (København 1992), 89.

2 Se, bl.a., A. Gastoué, "Une inédite prose contre les Normands pour la Fête de la Toussaint", i La Tribune de Saint-Gervaise xviii (Paris 1912), 220-5, 257-62, og B. Stäblein, "Die Sequenzmelodie 'Concordia' und ihr geschichtlicher Hintergrund", i Festschrift Hans Engel (Kassel 1964), 36492.

3 Københavns Universitet, Arnamagnæanske Samling (=A.M.) MS 28, $8^{0}$.

4 J. Bergsagel, "Songs for St. Knud the King", i Musik of forskning vi (1980), 152.

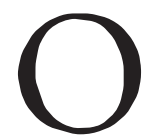
gså den enstemmige "Crist undhæ megh then helighanz nadhæ" i den omtalte "skolelærers håndbog" er på dansk og en anden, "Mith hierthæ brendher heth som boll", blander dansk og latin. Håndskriftet er en vigtig kilde til digte på dansk, og sandsynligvis har også andre af digtene været beregnet til at synge, men kun disse to er overleveret med deres melodier som de første, efter at den berømte Dromte mik en drom $i$ nat ca. 1320 blev skrevet $\mathrm{i}$ runer på en ledig plads i en afskrift af den Skånske Lov. Nogle af sangene i det danske håndskrift træffes igen i den berømte finske samling Piae Cantiones, ${ }^{16}$ der blev trykt i 1582, og som på sit titelblad udtrykkeligt henvender sig "til brug i kirke og skole". Men da havde de nordiske lande oplevet reformationen og bevæget sig ud af middelalderen.

5 Kiel, UB MS S.H. 8 A 8".

6 Dette var forst bemærket af H.V. [Dom Anselm] Hughes i Latin Hymnody (London 1922), 36-8, og senere omtalt af J.

Handschin, "Das älteste Dokument für die Pflege der Mehrstimmigkeit in Dänemark", i Acta Musicologica vii (1935), 67-71.

7 J. Bergsagel, "Liturgical Relations between England and Scandinavia, as seen in selected musical fragments from the 12th and 13th centuries", i Föredrag och Diskussionsinlägg frän Nordiskt Kollokvium III i Latinsk

Liturgiforskning (Helsingfors 1975), 11-26; se også den samme forfatters "The Practice of cantus planus binatim in Scandinavia in the 12th to 16th Centuries", i Le polifonie primitive in Friuli e in Europa, a cura di C. Corsi e P. Petrobelli (Roma 1989), 63-82. 
8 Lund, UB, faksimile i Angul Hamme-rich, Musikmindesmarker fra Middelalderen $i$ Danmark (Leipzig 1912), 15-40.

9 København, Rigsarkivet, frag. E 71; faksimile i udstillingskatalog Kalmarunionen 600 ar: Margrethe I, red. P. Grinder-Hansen (København 1996), 178.

10 C.A. Moberg, "Om flerstämmig musik i Sverige under medeltiden", i Svensk tidskrift for musikforskning $\mathrm{x}$ (1928), 5-92.

$"$ København, Kgl. Bibl. GkS 1810, $4^{\circ}$.

12 J. Bergsagel, "The Transmission of Notre Dame Organa in Some Newly-Discovered Magnus liber organi Fragments in Copenhagen", i Atti del XIV Congresso dell Societd Internazionale di Musicologia, Bologna, 27 agosto - $1^{\circ}$ settembre 1987, iii (Turin 1990), 629-36.
13 J. Bergsagel, "At notere musikalsk rytme i middelalderen: en ny kilde", i Musik \& forskning xviii (1992-3), 7-31.

14 Københavns Universitet, A.M. MS 76, 8, udg. i faksimile med transskription af $S$. Kroon m.fl., som $A$ Danish Teacher's Manual of the Mid-Fifteenth Century, i Skrifter udgivna af Vetenskapssocieteten i Lund 85 (Lund 1993).

is J.Bergsagel, "Nicolai solempnia - Another Polyphonic Benedicamus domino Trope in a Danish Source", i Festskrift Soren Sorensen (København 1990), 1-17.

16 Ed. G. Woodward (London 1910); faks. udg., Documenta musicae fennicae, $x$ (Helsingfors 1967). 